genesis. In the present review it is not necessary to enter into a discussion of such details. But there can be no doubt that Prof. Sinnott has produced an important and impressive book, one which seems likely to stimulate and hold its place in university teaching and research for many years to come.

C. W. WARDLAW

\section{MODERN ARMAMENTARIUM OF THERAPEUTICS}

Medicinal Chemistry

Edited by Prof. Alfred Burger. Second edition. Pp. xiii +1243. (New York : Interscience Publishers, Inc.; London: Interscience Publishers, Ltd., 1960.) $280 s$.

$T$ is the usual procedure that second editions of successful books are corrected versions of the original opus, with certain parts brought up to date. Prof. Alfred Burger must have faced a difficult decision when changing his role from that of sole author of the first edition to that of editor-in-chief and part-author of the new volume, at the same time re-organizing its contents. With due regard to his achievement as represented by the older version, it was a wise decision-because he has assembled around him an impressive list of contributors, holding industrial as well as academic or Government positions, but still reserving for himself the lion's share. The choice of one instead of two volumes is perhaps less fortunate as the weight of the present tome prevents one from reading certain chapters with leisure after working hours. It is also a matter for slight criticism that he selected an all-American team, which, in spite of the high standing of the individual scientists, diminishes somewhat the threads of internationel connexions so closely interwoven with successful research.

That does not mean that the writers on various aspects of medicinal chemistry (which, as Burger points out, can be equated with pharmaceutical chemistry and represents one very important chapter of applied organic chemistry plus pharmacology, experimental pathology and microbiology, etc.) have neglected results not originating with efforts in the United States. But with the best of intentions for fair play, a certain 'parochial' note creeps in sometimes, the reference to proprietary names, to major illnesses and pharmaceutical sales, to cholinergic instead of parasympathomimetics and to adrenergic instead of sympathomimetic drugs (Dale clearly reserved the expressions 'cholinergic' and 'adrenergic' for structures and nerves of the autonomic system). It should be said that only a very close study of the book discloses these relatively unimportant shortcomings ; the overall impression is favourable, with the consequence that this volume will acquire many friends in many countries.

If a fow suggestions for the third edition may be added, these are examples : an overall division into symptomatic, etiotropic (chemotherapeutic) remedies and drugs for restitutional therapy could have been given as a table and used as chapter-grouping; the historical table (2-11) has a few omissions, for example, Kennaway's name against experimental carcinogenesis and Todd's name against thiamine synthesis; action mechanism of central nervous system depressors ignores McIlwain's most vital contributions, and the difference between curare and curareform drugs and the methonium compounds is not sufficiently brought out; it is also a pity that little is said about the cannabinols mentioned only under "Analeptics", and very briefly under "Drugs for Hyperkinetic Disorders", although the synthetic derivatives represent an interesting and early group of psychopharmacological agents (formula 23-X and the name 'cannabadiol' are incorrect). Finally, an alphabetical list of authors after the subject index would have helped enormously if looking for specific references.

As said in my review of the first edition (Research, $4,438 ; 1951)$ it is easy to criticize, but a very difficult task to write, such a book, and I should add even more so to edit the new version with its many improvements and attractive features.

F. BERGEL

\section{BIRDS AND MEN IN BORNEO}

\section{The Birds of Borneo}

By Bertram E. Smythies. With special chapters by Tom Harrisson, Lord Medway, and J. D. Freeman. Pp. xvi $+562+99$ plates. (Edinburgh and London: Oliver and Boyd, Ltd., 1960.) 84s. net.

HIS is a very unusual bird book. The main body of the work (about 460 pages) consists of a detailed systematic account of all the 549 species of birds that have been found in Borneo. It is written with the competence and thoroughness that distinguishes the author's previous volume on the birds of Burma. The articles dealing with the regular members of the fauna give the world distribution and Bornean status of each species, an adequate description, and discuss the habits, voice, food, and nest and eggs; the irregular visitors and casuals are treated more briefly. Appendixes contain the history of Bornean ornithology, an exhaustive bibliography, indexes of place-names, and of Malay and Iban names; and there is a large folding topographical sketch-map of Borneo. The illustrations, which are of very high quality, consist of 29 photographic plates and 50 plates in colour depicting 434 species from drawings by Commander A. M. Hughes.

But it is the hundred pages that precede this excellent treatise that put this book in a class apart. The first three chapters comprise an introduction, $a$ topographical description of Borneo, with a discussion of the varied habitats that the island provides, and an account of bird migration in Borneo. These are followed by four chapters of ornitho-anthropology by Mr. Tom Harrisson, Lord Medway, and Dr. J. D. Freeman which are of the greatest interest. Harrisson says : "There is probably no other part of the world where birds and men are more intimately mixed than in Borneo", and goes on to discuss "Man $v$. Bird v. Man", "Man-Bird double-thinking" and many other matters, from Borneo's wild men and their bird values to hornbill ivory (more precious than jade), feather jewellery, and birds and the human stomach. This chapter overflows with informatiun and ideas, and though it would gain in clarity with fewer parentheses it would lose much of its charac. teristic style. Lord Medway's chapter gives a fascinating account of the cave swiftlets, the saliva-built nests of which are the edible birds' nests of commerce, and which echo-navigace in the 